\title{
PENGARUH KEPRIBADIAN DAN KEPUASAN KERJA TERHADAP ORGANIZATIONAL CITIZENSHIP BEHAVIOR GURU SEKOLAH MENGAH ATAS NEGERI DI KECAMATAN BEKASI UTARA, BEKASI.
}

\author{
Imanda Priskila Sinamo. ${ }^{1}$
}

\begin{abstract}
The purpose of this research is to determine the effect of personality and job satisfaction on organizational citizenship behavior the teacher sma the district of noth bekasi. The research methodology was survey which were selected by simple random sampling technique. Analysis and interpretation of the data indicate that (1) personality has a positive direct effect in organizational citizenship behavior, (2) job satisfaction has a positive direct effect in organizational citizenship behavior, (3) personality has a positive direct effect in job satisfaction.
\end{abstract}

Keywords: personality, job satisfaction, organizational citizenship behavior.

\section{PENDAHULUAN}

Badan Program Pembangunan PBB (UNDP) kembali merilis Indeks Pembangunan Manusia (IPM) terbaru untuk tahun 2013. Dalam laporan mereka, Indonesia berada di peringkat 108 dari 187 negara yang dinilai. Pada 2013, nilai IPM Indonesia adalah 0,684 . Angka tersebut meningkat 0,003 poin dari tahun 2012, yakni 0,681 . Dengan nilai 0,684, Indonesia berada dalam kategori negara dengan pembangunan manusia sedang. Khusus Indonesia, menurut Beate, peringkat IPM Indonesia tahun 2013 tidak mengalami pergeseran dari tahun 2013, yakni pada posisi 108. "Di ASEAN, Indonesia berada di atas Myanmar, Laos, Kamboja, Timor-Leste, Vietnam dan Filipina, dan berada di bawah Singapura, Brunei, Malaysia dan Thailand.

Dalam UU No. 20/2003 tentang Sistem Pendidikan Nasional (Sisdiknas) Pasal 3 disebutkan bahwa, Pendidikan nasional berfungsi mengembangkan kemampuan dan membentuk watak serta peradaban bangsa yang bermartabat dalam rangka mencerdaskan kehidupan bangsa, bertujuan untuk berkembangnya potensi peserta didik agar menjadi manusia yang beriman dan bertakwa kepada Tuhan Yang Maha Esa, berakhlak mulia, sehat, berilmu, cakap, kreatif, mandiri, dan menjadi warga negara yang demokratis serta bertanggung jawab.

Sudijarto dalam E. Mulyasa menyatakan bahwa sumber daya manusia yang dibutuhkan adalah yang memiliki kemampuan menguasai, menerapkan dan mengembangkan IPTEK, serta daya saing yang tinggi. Manusia yang demikian hanya dapat dikembangkan melalui sistem pendidikan yang dapat merangsang dan menantang otak, menyentuh dan menggerakkan qolbu, serta mampu mendorong dan membangkitkan nafsu peserta didik untuk melakukan tindakan nyata berdasarkan pengetahuan dan keyakinan akan kebenaran yang dikuasainya dengan penuh tanggung jawab.

Guru sebagai tenaga kependidikan dituntut memiliki kinerja yang mampu memberikan dan merealisasikan harapan dan keinginan semua pihak terutama masyarakat umum yang telah mempercayai sekolah dan guru dalam membina anak didik. Dalam meraih mutu pendidikan yang baik sangat dipengaruhi oleh kinerja guru dalam melaksanakan tugasnya sehingga kinerja guru menjadi tuntutan penting untuk

1 Staff ahli di Yayasan Sinamo. 
mencapai keberhasilan pendidikan. Secara umum mutu pendidikan yang baik menjadi tolak ukur bagi keberhasilan kinerja yang ditunjukkan guru.

Dalam pelaksanaan tugasnya mendidik, guru memiliki sifat dan perilaku yang berbeda, ada yang bersemangat dan penuh tanggung jawab, juga ada guru yang dalam melakukan pekerjaan itu tanpa dilandasi rasa tanggung jawab, selain itu juga ada guru yang sering membolos, datang tidak tepat pada waktunya dan tidak mematuhi perintah. Kondisi guru seperti itulah yang menjadi permasalahan di setiap lembaga pendidikan formal. Dengan adanya guru yang mempunyai kinerja rendah, sekolah akan sulit untuk mencapai hasil seperti yang diharapkan. Informasi yang diperoleh dari kepala bidang pendidikan menengah bapak Alie Fauzie, kesadaran guru-guru untuk membantu rekan kerjanya masih kurang terutama di sekolah negeri. Para guru kurang berinisiatif dalam membantu rekan guru yang sibuk mengerjakan pekerjaan sekolah, kecuali para guru dilibatkan dalam suatu kepanitiaan. Rendahnya kuatitas sumber daya manusia tentunya akan menimbulkan dampak negatif bagi organisasi maupun guru itu sendiri.

$O C B$ merupakan perilaku individu yang ekstra, yang tidak secara langsung atau eksplisit dapat dikenali dalam suatu sistem kerja yang formal, dan yang secara agregat mampu meningkatkan efektivitas fungsi organisasi. Organisasi pada umumnya percaya bahwa untuk mencapai keunggulan harus mengusahakan kinerja individual yang setinggi-tingginya, karena pada dasarnya kinerja individual mempengaruhi kinerja tim atau kelompok kerja dan pada akhirnya mempengaruhi kinerja organisasi secara keseluruhan.

Kinerja yang baik menuntut perilaku guru yang diharapkan sesuai dengan organisasi. Perilaku yang menjadi tuntutan organisasi saat ini adalah tidak hanya perilaku in-role, tetapi juga perilaku extra-role. Perilaku extra-role ini disebut juga dengan $O C B$. $O C B$ merupakan istilah yang digunakan untuk mengidentifikasikan perilaku guru sehingga dia dapat disebut sebagai anggota yang baik. Perilaku ini cenderung melihat seseorang (guru) sebagai makhluk sosial (menjadi anggota organisasi), dibandingkan sebagai makhluk individual yang mementingkan diri sendiri.

Jika guru dalam organisasi memiliki $O C B$, maka usaha untuk mengendalikan guru menurun, karena guru dapat mengendalikan perilakunya sendiri atau mampu memilih perilaku terbaik untuk kepentingan organisasinya. Borman dan Motowidlo (1993) menyatakan bahwa OCB dapat meningkatkan kinerja organisasi (organizational performance) karena perilaku ini merupakan "pelumas" dari mesin sosial dalam organisasi, dengan kata lain dengan adanya perilaku ini maka interaksi sosial pada anggota-anggota organisasi menjadi lancar, mengurangi terjadinya perselisihan, dan meningkatkan efisiensi.

Perilaku ini muncul karena perasaan sebagai anggota organisasi dan merasa puas apabila dapat melakukan suatu yang lebih kepada organisasi. Perasaan sebagai anggota dan puas bila melakukan suatu yang lebih hanya terjadi jika guru memiliki persepsi yang positif terhadap organisasinya. $O C B$ merupakan tindakan seseorang di luar kewajibannya, tidak memperhatikan kepentingan diri sendiri (Sloat, 1999), tidak membutuhkan deskripsi pekerjaan (job description) dan sistem imbalan formal, bersifat sukarela dalam bekerjasama dengan teman sekerja dan menerima perintah secara khusus tanpa keluhan.

Bertitik tolak dari keadaan di atas, maka peneliti memandang perlu adanya penelitian yang mengungkapkan pengaruh kepemimpinaan transformasional dan selfefficacy terhadap motivasi. Peneliti akan melakukan penelitian dengan judul "pengaruh kepemimpinaan transformasional dan self-efficacy terhadap motivasi guru SD Negeri Di Kecamatan Kramat Jati, Jakarta Timur. 


\section{Organizational Citizenship Behavior}

OCB merupakan perilaku individu yang ekstra dari kewajibannya, yang tidak secara langsung atau eksplisit dapat di kenali dalam suatu System kerja yang formal dan secara agregat mampu meningkatkan efektivitas fungsi organisasi. Menurut Paul E. Spector (1997:57) OCB adalah perilaku oleh pegawai dimaksudkan untuk membantu rekan kerja atau organisasi, "organizational citizenship behavior or OCB is behavior by an employee intended to help coworkers or the organization". OCB menggambarkan perilaku individu yang memiliki kebebasan untuk memilih, tidak secara langsung atau secara eksplisit diakui oleh sistem penghargaan formal, dan secara keseluruhan mendorong efisiensi dan efektivitas fungsi organisasi. Menurut Colin P. Silverthone (2005:180) mengatakan, "organizational citizenship behavior represent individual behavior that is discretionary, not directly or explicitly recognized by the formal reward system, and in the aggregate promotes the efficient and effective functioning of the organization". Organizational citizenship behavior merupakan perilaku individu yang diskresi, tidak langsung atau eksplisit diakui oleh sistem penghargaan formal, dan secara agregat mempromosikan fungsi efisien dan efektif organisasi. Pendapat senada diungkapkan oleh Jason A. Colquitt, Jeffery A. LePine, Michael J. Wesson (2015:39) Citizenship Behavior adalah, "citizenship behavior is defined as voluntary employee activities that may or may not be rewarded but that contibute to the organization by improving the overall quality of the setting in which work takes place". Citizenship behavior didefinisikan sebagai kegiatan sukarela karyawan yang mungkin atau mungkin tidak dihargai, tetapi berkontribusi untuk meningkatkan kualitas organisasi secara keseluruhan dengan pengaturan di mana pekerjaan berlangsung.

Sedangkan Bolino, M.C., Turnley, W.H., Bloodgood (2002:205) yang di kutip oleh Organ, "organizational citizenship behavior is the behavior of corporate employees who intended to enhance the effectiveness of corporate performance without sacrificing the productivity purposes of individual employees". Organizational citizenship behavior merupakan perilaku karyawan perusahaan yang ditujukan untuk meningkatkan efektifitas kinerja sekolah tanpa mengabaikan tujuan produktivitas individual karyawan. Senada yang di ungkapkan oleh John W. Newstrom (2011:232) organizational citizenship behavior adalah, "organizational citizenship behavior, which are discretionary and helpful actions above and beyond the call of duty that promote the organization's success". OCB adalah kebebasan menentukan dan tindakan sangat menolong di atas dan di luar panggilan tugas yang mempromosikan sukses organisasi.

Berdasarkan beberapa deskripsi konsep yang dipaparkan di atas, maka dapat disintesiskan $O C B$ adalah tindakan anggota organisasi yang muncul secara sukarela membantu individu lain berkaitan dengan tugas dan pekerjaan organisasi dengan indikator 1). Altruism (perilaku membantu) 2). Conscientiousness (mengacu kepada tepat waktu) 3). Sportmanship (menghindari keluhan) 4). Courtesy (Kesopanan) dan 5). Civic virtue (partisipasi tanggung jawab dalam kehidupan politik organisasi).

\section{Kepribadian}

Istilah ini menggambarkan sifat khas mengacu pada cara individu menghadapi kehidupan. Kepribadian adalah konsep yang luas dan terpadu. Ricky W. Grifin, Gregory Moorhead (2014:66) mendefinisikan kepribadian sebagai berikut, "personality is the relatively stable set of psychological attributes that distinguish one person from another". Kepribadian adalah himpunan relatif stabil atribut psikologis yang membedakan satu orang dari yang lain. Selanjutnya Robert P. Vecchio (2006:26), "personality can be defined 
as the relatively enduring individual traits and dispositions that form a pattern distinguishing one person from all others". Kepribadian dapat didefinisikan sebagai ciri-ciri individu yang relatif abadi dan disposisi yang membentuk pola membedakan satu orang dari yang lain. Menurut Gordon Allport yang dikutip oleh Stephen P. Robbins, Timothy A. Judge (2015:154), "personality is the dynamic organization within the individual of those psychophysical systems that determine his unique adjustment to his environment". Kepribadian adalah organisasi yang dinamis dalam diri individu dari sistem-sistem psikofisik yang menentukan penyesuaian yang unik terhadap lingkungan. Robert Kreitner, Angelo Kiniciki (2011:133) mendefinisikan kepribadian sebagai berikut, "personality is defined as the combination of stable physical and mental characteristics that give the individual his or her identity". Kepribadian didefinisikan sebagai kombinasi dari karakteristik fisik dan mental yang stabil yang memberikan identitas pada individunya. Selanjutnya James Campbell Quick, Debra L. Nelson (2013:74), "personality is defined as a relatively stable set of characteristics that influence an individual's behavior." Kepribadian merupakan sesuatu yang khas dan relatif tahan lama tetang cara berpikir, merasa, dan bertindak yang menjadi ciri seseorang dalam menanggapi situasi kehidupan dan sikap yang stabil.

Sedangkan Jerald Greenberg, Robert A. Baron (2008:135), "personality is the unique and relatively stable pattern of behavior, thoughts, and emotions shown by individuals". Kepribadian adalah pola yang unik dan relatif stabil perilaku, pikiran, dan emosi yang ditunjukkan oleh individu. Selanjutnya Steven McShane, Mara Olekalns, Tony Travaglione (2013:43), "personality is the relatively enduring pattern of thoughts, emotions and behaviors that characterize a person, along with the psychological process behind those characteristics". Kepribadian adalah pola yang relatif abadi pikiran, emosi, dan perilaku yang menjadi ciri seseorang, bersama dengan proses psikologis di balik karakteristik.

John R. Schemerhon, JR, Richard N. Osborn, Mary Uhl-Bien, James G. Hunt (2012:29), "personality is the overall combination of characteristics that capture the unique nature of a person as that person reacts to and interacts with others". Kepribadian adalah kombinasi keseluruhan karakteristik yang menangkap sifat unik dari seseorang sebagai orang yang bereaksi terhadap dan berinteraksi dengan orang lain. Don Hellriegel, John W. Slocum, Jr (2011:70), "personality represent the overall profile or combination of stable psychological attributes that capture the unique nature of person." Oleh karena itu, kepribadian menggabungkan seperangkat karakteristik fisik dan mental yang mencerminkan bagaimana seseorang melihat, berpikir, bertindak dan merasa.

Berdasarkan beberapa deskripsi konsep yang dipaparkan di atas, maka dapat disintesiskan, kepribadian adalah karakteristik seseorang yang dinamis dan terintegrasi yang termanifestasi dalam cara berpikir, merasakan dan bertindak secara unik dan stabil yang mencirikan tanggapan seseorang terhadap situasi yang meliputi faktor-faktor kepribadian yaitu kesungguhan, keramahan, keterbukaan, ekstraversi dan sifat hatihati.

\section{Kepuasan Kerja}

Konsep kepuasan kerja menurut Laurie J.Mullins (2010:282) adalah konsep yang rumit, "job satisfaction is a complex and multifaceted concept, which can mean different things to different people". Karena menurutnya, kepuasan kerja dapat memiliki arti berbeda bagi masing-masing orang. Kepuasan kerja merupakan salah satu faktor yang harus diperhatikan dalam upaya meningkatkan kinerja pegawai. Menurut John $\mathrm{R}$. Schermerhorn (2011:388) mendefinisikan kepuasan kerja, "job satisfaction is the degree to which an individual feels positive or negative about various aspcets of work". Kepuasan kerja adalah sejauh mana seseorang merasa positif atau negatif tentang berbagai aspek 
pekerjaan. Pendapat yang hampir serupa dikemukakan oleh Stephen P. Robbins, Timothy A. Judge (2015:102) berpendapat bahwa, "job satisfaction is a positive feeling about a job resulting from an evaluation of its characteristics is clearly broad". Kepuasan kerja adalah perasaan positif tentang pekerjaan sebagai hasil dari evaluasi pada suatu karakter adalah jelas digambarkan.

Jason Colquitt Jeffery A. Lepine, Michael J. Wesson (2015:98) menyatakan bahwa, "job satisfaction is defined as a pleasurable emotional state resulting from the appraisal of one's job or job experiences". Kepuasan kerja didefinisikan sebagai keadaan emosional yang menyenangkan yang dihasilkan dari penilaian dari pekerjaan atau pengalaman kerja. Selanjutnya James L. Gibson, James H. Donnelly, Jr, John M. Ivancevich, Robert Konopaske (2012:102), "job satisfaction is an attitude that individuals have about their jobs. it results from their perceptions of their jobs, based on factors of the work environment, such as the supervisor style, policies and procedures, work group affiliation, working condition, and fringe benefits". Kepuasan kerja adalah sikap bahwa individu memiliki tentang pekerjaan mereka. Itu hasil dari persepsi mereka tentang pekerjaan mereka, berdasarkan faktor-faktor lingkungan kerja, seperti gaya pengawas, kebijakan dan prosedur, afiliasi kelompok kerja, kondisi kerja, dan tunjangan.

Berdasarkan definisi konsep yang telah diuraikan dapat disintesiskan bahwa kepuasan kerja adalah respon perasaan berupa senang atau tidak senang seseorang dalam bekerja dan pengalaman kerjanya untuk mencapai tujuan organisasi, dengan indikator: perasaan terhadap keberhasilan dalam bekerja, perasaan terhadap rekan kerja, perasan terhadap memperoleh penghargaan, perasaan terhadap tanggung jawab dan perasaan terhadap kesempatan mengembangkan diri.

\section{METODE PENELITIAN}

Penelitian ini menggunakan metode survey dengan teknik analisis jalur (path analys) Data penelitian ini dikumpulkan dengan cara memilih sampel dalam populasi. Populasi terjangkau dalam penelitian ini adalah seluruh guru sekolah menengah atas di Kecamatan Bekasi Utara, yang berjumlah 109 guru. Dan perhitungan dengan menggunakan slovin, maka di peroleh jumlah sampel sebanyak 86 guru yang dijadikan sampel frame dalam penelitian ini. Pengumpulan data digunakan untuk penelitian ini adalah statistika deskriptif dan statistika inferensial.

\section{HASIL PENELITIAN DAN PEMBAHASAN}

Pengaruh kepribadian terhadap $O C B$.

Dari hasil pengujian hipotesis pertama dapat disimpulkan bahwa terdapat pengaruh langsung positif kepribadian terhadap OCB dengan nilai koefisien korelasi sebesar 0,463 dan nilai koefisien jalur sebesar 0,352. Ini memberikan makna kepribadian berpengaruh langsung terhadap OCB. Menurut Colin P. Silverthone (2005:180) mengatakan, "organizational citizenship behavior represent individual behavior that is discretionary, not directly or explicitly recognized by the formal reward system, and in the aggregate promotes the efficient and effective functioning of the organization". Organizational citizenship behavior merupakan perilaku individu yang diskresi, tidak langsung atau eksplisit diakui oleh sistem penghargaan formal, dan secara agregat mempromosikan fungsi efisien dan efektif organisasi. Pendapat senada diungkapkan oleh Jason A. Colquitt, Jeffery A. LePine, Michael J. Wesson (2015:39) Citizenship Behavior adalah, "citizenship behavior is defined as voluntary employee activities that may or may not be rewarded but that contibute to the organization by improving the overall quality of the setting in which work takes place". Citizenship behavior didefinisikan sebagai kegiatan sukarela karyawan 
yang mungkin atau mungkin tidak dihargai, tetapi berkontribusi untuk meningkatkan kualitas organisasi secara keseluruhan dengan pengaturan di mana pekerjaan berlangsung.

Hasil penelitian ini senada dengan pendapat beberapa ahli di antaranya adalah Jason A. Colquitt, Jeffery A. LePine, Michael J. Wesson menjelaskan bahwa kepribadian bagian terpenting untuk terwujud atau terciptanya $\mathrm{OCB}$, demikian pernyataannya: "three important point should be emphasized about citizenship behavior. First as you have probably realized, citizenship behaviors are relevant in virtually any job, regardless of the particular nature of its taks and research suggest that these behaviors can boost organizational effectiveness. Second because citizenship behavior are relatively discretionary and influenced by the specific situation the employees is working in they vary significantly over time. Third, from an employee's perspective, it may be tempting to discount the important of citizenship behaviors to just focus on your own job task and leave aside any extra stuff. Tiga poin penting yang harus ditekankan tentang perilaku kewarganegaraan untuk guru. Pertama, perilaku kewarganegaraan yang relevan di hampir pekerjaan apapun, terlepas dari sifat tertentu dan penelitian menunjukkan bahwa perilaku ini dapat meningkatkan efektivitas organisasi. Kedua karena perilaku kewarganegaraan relatif diskresioner dan dipengaruhi oleh situasi tertentu, guru yang bekerja, guru bervariasi secara signifikan dari waktu ke waktu. Ketiga, dari perspektif guru, mungkin tergoda untuk pentingnya perilaku kewarganegaraan hanya fokus pada tugas pekerjaannya sendiri dan kesampingkan saja hal ekstra.

Menurut Robert Kreitner, Angelo Kinicki menyatakan, "organizational citizenship behaviors $(O C B)$ consist of employee behaviors that are beyond the call of duty. example include such gestures as constructive statements about the department, expression of personal interest in the work of others, suggestions for improvement, training new people, respect for the spirit as well as the letter of housekeeping rules, care for organizational property, and punctuality and attendance well beyond standard or enforceable levels. managers certainly would like employees to exhibit these behaviors". Organizational citizenship behaviors (OCB) terdiri dari perilaku guru yang berada di luar panggilan tugas. Contoh termasuk gerakan seperti laporan konstruktif mengenai siswaa, pengungkapan kepentingan pribadi dalam pekerjaan guru lain, saran untuk perbaikan, guru-guru baru dalam proses pelatihan, menghormati semangat kerja guru lain dan menciptakan aturan main, melakukan perawatan untuk properti sekolah, dan ketepatan waktu hadir di sekolah dan kehadiran jauh melampaui tingkat standar yang sudah di tentukan atau memaksa para kepala sekolah pasti ingin guru-gurunya untuk menunjukkan perilaku ini.

\section{Pengaruh kepuasan kerja terhadap $O C B$.}

Dari hasil pengujian hipotesis kedua dapat disimpukan bahwa terdapat pengaruh langsung positif kepuasan kerja terhadap OCB dengan nilai koefisien korelasi sebesar 0,454 dan nilai koefisien jalur sebesar 0,339. Ini memberikan makna kepuasan kerja berpengaruh langsung terhadap OCB. Menurut John R. Schermerhorn (2011:388) mendefinisikan kepuasan kerja, "job satisfaction is the degree to which an individual feels positive or negative about various aspcets of work". Kepuasan kerja adalah sejauh mana seseorang merasa positif atau negatif tentang berbagai aspek pekerjaan. Pendapat yang hampir serupa dikemukakan oleh Stephen P. Robbins, Timothy A. Judge (2015:102) berpendapat bahwa, "job satisfaction is a positive feeling about a job resulting from an evaluation of its characteristics is clearly broad". Kepuasan kerja adalah perasaan positif tentang pekerjaan sebagai hasil dari evaluasi pada suatu karakter adalah jelas digambarkan. 
Hasil penelitian ini senada dengan pendapat beberapa ahli di antaranya adalah James Campbell Quick, Debra L. Nelson mengatakan bahwa kepuasan kerja adalah salah satu faktor terciptanya sikap $O C B$, berikut: "job satisfaction is related to many other important personal and organizational outcomes, such as $O C B$, which is voluntary behavior above and beyond the call of duty. Satisfied employees are more likely to make positive comments about the company, refrain from complaining when things at work do not go well, and help their coworkers". Kepuasan kerja banyak berhubungan dengan kepentingan pribadi dan kepentingan organisasi, seperti perilaku kewarganegaraan organisasi (OCB), yang merupakan perilaku sukarela atas pekerjaan dan melampaui kewajiban tugasnya. Guru yang merasa puas lebih mungkin untuk membuat komentar positif tentang sekolah, menahan diri dari mengeluh ketika hal-hal di tempat kerja tidak berjalan dengan baik dan membantu rekan kerja guru lain yang mengalami kesulitan. James L. Gibson, James H. Donnelly, Jr, John M. Ivancevich, Robert Konopaske, "job satisfaction is an attitude that individuals have about their jobs. it results from their perceptions of their jobs, based on factors of the work environment, such as the supervisor style, policies and procedures, work group affiliation, working condition, and fringe benefits". Kepuasan kerja adalah sikap bahwa guru memiliki tentang pekerjaannya. Itu hasil dari persepsi guru tentang pekerjaannya, berdasarkan faktor-faktor lingkungan kerja, seperti gaya pengawas sekolah, kebijakankebijakan yang berlaku di sekolah dan prosedur aturan yang berlaku, afiliasi kelompok kerja guru yang sudah berjalan.

\section{Pengaruh kepribadian terhadap kepuasan kerja.}

Dari hasil pengujian hipotesis ketiga dapat disimpulkan bahwa terdapat pengaruh langsung positif kepribadian terhadap kepuasan kerja dengan nilai koefisien korelasi sebesar 0,327 dan nilai koefisien jalur sebesar 0,327. Ini memberikan makna kepribadian berpengaruh langsung terhadap kepuasan kerja. Ricky W. Grifin, Gregory Moorhead (2014:66) mendefinisikan kepribadian sebagai berikut, "personality is the relatively stable set of psychological attributes that distinguish one person from another". Kepribadian adalah himpunan relatif stabil atribut psikologis yang membedakan satu orang dari yang lain. Selanjutnya Robert P. Vecchio (2006:26), "personality can be defined as the relatively enduring individual traits and dispositions that form a pattern distinguishing one person from all others". Kepribadian dapat didefinisikan sebagai ciri-ciri individu yang relatif abadi dan disposisi yang membentuk pola membedakan satu orang dari yang lain. Menurut Gordon Allport yang dikutip oleh Stephen P. Robbins, Timothy A. Judge (2015:154), "personality is the dynamic organization within the individual of those psychophysical systems that determine his unique adjustment to his environment". Kepribadian adalah organisasi yang dinamis dalam diri individu dari sistem-sistem psikofisik yang menentukan penyesuaian yang unik terhadap lingkungan.

Hasil penelitian ini senada dengan pendapat beberapa ahli di antaranya adalah James L. Gibson, John M. Ivancevich, James H. Donnelly, Jr, Robert Konopaske menjelaskan bahwa bagian dari kepribadian yaitu extraversion dan introversion memiliki dampak terhadap kepuasan kerja guru berikut pernyataannya, "extraversionintroversion. The degree to which a person is sociable, gregarious and assertive versus reserved, quiet and timid. Research has been reported that extroverted people tend to perform well in sales and management jobs, do better in training programs and have higher levels of overall job satisfaction". Extraversion-introversi. Sejauh mana guru bergaul, suka berteman dan tegas terhadap undang teman, tenang dan pemalu. Penelitian telah melaporkan bahwa guru ekstrovert cenderung tampil baik dalam pekerjaan dan manajemen, lebih baik 
dalam program pelatihan dan memiliki tingkat yang lebih tinggi dari kepuasan kerja secara keseluruhan.

\section{PENUTUP}

Kesimpulan: 1) kepribadian berpengaruh langsung positif terhadap OCB. Artinya kepribadian yang baik akan mewujudkan sikap OCB didalam setiap diri guru. 2) kepuasan kerja berpengaruh langsung positif terhadap $O C B$. Artinya kepuasan yang tercipta didalam diri guru ketika bekerja akan meningkatkan $O C B$ guru didalam bersikap selama di sekolah. 3) kepribadian berpengaruh langsung positif terhadap kepuasan kerja. Artinya kepribadian yang baik akan mewujudkan kepuasan dalam bekerja dan akan tercermin dalam sikap guru selama bekerja.

Saran: 1) bagi kepala Dinas Pendidikan Kota Bekasi, perlunya perhatian dalam setiap pengambilan kebijakan dengan menjadikan landasan mengenai kepuasan kerja dan kepribadian guru-guru SMA Negeri di Kota Bekasi. 2) bagi kepala sekolah dapat meningkatkan $O C B$ guru dengan memperhatikan masing-masing kepribadian guru guna untuk menciptkan suasana yang kondusif dan nyaman dalam upaya mewujudkan kepuasan kerja untuk semua dan akan lahirlah sikap $O C B$ sesama guru dalam bekerja. 3) bagi peneliti lain, rendahnya derajat mengkaji lebih lanjut terkait dengan faktor-faktor lain yang berpengaruh terhadap $O C B$.

\section{DAFTAR PUSTAKA}

Campbell, James, Quick, Debra 1 Nelson, Principles of Organizational Behavior Realities and Challenges 8 edition. China: South-Western Cengange Learning 2013.

Colquitt, Jason A., Jeffrey A, Lepine and Michael J Wesson, organization behavior improving performance and commitment in the workplace 4 edition. New York: Mc Graw Hill 2015.

Greenberg, Jerald, behavior in organizations 10 edition. England: Pearson Education Limited, 2011.

Greenberg, Jerald, Robert A. Baron. Behavior in Organization 9 edition. New Jersey: Pearsin Prentice Hall, 2008.

Grifin, Ricky W., Gregory Moorhead, Organizational Behavior Managing People and Organizational 11 edition. USA: South Western Cengange Learning,2014.

Hellriegel, Don, John W. Slocum, Organizational Behavior. New York: Nelsom Education,Ltd, 2011.

Ivancevich, John M., Robert Konopaske,Michael T. Matteson, Organizational Behavior and Management. New York: McGraw-Hill Companies, Inc., 2011.

Kinicki, Angelo, Brian K. Wiliams, Management a Practical Introduction. New York: McGraw-Hill,2011.

Kreitner, Robert, Angelo Kinicki, Organizational Behavior. New York: McGraw-Hill Companies, Inc., 2010. 
Lussier Robert N, Humen Relations in Organizationals Applications and Skill Building, 9 Edition (New York : McGraw-Hill, 2013.

McShane, Steven L., Mara Olekalns, Tony Travaglione, Organizational Behavior Emerging Knowledge. Global insight 4 edition. Asia: McGraw Hill, 2013.

McShane, Steven L., Mary Ann Von Glinov, Organizational Behaviour Emerging Realities for The Workplace Revolution 5 edition. New York: McGraw-Hill Comapanies,Inc., 2010 